Mouse patent a step closer

\section{Munich}

IN an important case for the European biotechnology industry, an appeals board at the European Patent Office (EPO) in Munich last week told patent examiners to reconsider their earlier decision that a transgenic mouse could not be patented. The mouse in question - the 'Oncomouse' - is produced by Du Pont Corporation and was patented successfully in the United States in 1988.

The Oncomouse carries human genes that increase its susceptibility to cancer and is widely used by cancer researchers. Other transgenic animals are already in use in medical and pharmaceutical laboratories and are expected eventually to revolutionize agriculture.

The original examiners had in June last year refused the patent on several grounds: first, that patents on "plant and animal varieties" are forbidden by Article 53(b) of the European Patent Convention (EPC); second, that the discovery had not been shown to be reproducible; and third, that patent law was not the appropriate tool for resolving the ethical questions raised by transgenic animals (see Nature 340, 85; 1989).

But the appeals board rejected the examiners' decision in all three instances. The board emphatically recommended that the examiners take up the issue of ethics and morality, which is specifically mentioned in Article 53(a) of EPC. According to Sandra Keegan, author of a European Commission directive concerning the patenting of animals and plants, the board is trying to amass a full range of arguments for and against the patent because the precedent is so important. The case will be a "tough nut to crack", says Keegan, especially since, according to an EPO spokesman, the examiners have a scientific and medical background and are by no means experts on ethics.

Du Pont argues that the market for transgenic animals in Europe will not develop without the same kind of patent protection that already covers marketing of the mouse in Europe. In the absence of a patent, it is trying to protect itself through licensing agreements.

In West Germany, environmentalists have objected vociferously to the idea of patenting animals because they consider it immoral and an affront to the natural order; animal breeders also object because they may be forced to pay licensing fees for each generation of animals that is derived from a patented animal. Last month, the Berlin-based Gen-Ethisches Netzwerk (gene-ethical network) advertised in the German press to try to raise money for a campaign against the patent, claiming that it would lead to exploitation of farmers in developing countries.
But Bob Beltz, a spokesman for Du Pont, says the activists have received more press coverage than their numbers warrant. "Don't underestimate the silent majority" who are in favour of animal patents, he says.

A European Commission proposal developed in the internal market directorate to increase patent protection for biotechnological discoveries including animals and plants has been bogged down for more than a year in the European Parliament. Keegan, who wrote the directive, says that although the issue is still an important one, the parliament has moved on to other issues. Its unwillingness to act reflects a lack of consensus among European countries, which in her opinion will be resolved not through political discussion but rather through the revision of international conventions such as the EPC.

Although EPO has been friendly to patent applications involving biotechnology, it may take years before the mouse patent case is settled for good. The first European plant patent was awarded last year to the US company Lubrizol for a method to insert genes that boost the ability to store proteins in plants, and for the cells obtained using this method. A challenge to the patent is still pending.

Steven Dickman

\title{
WHO concern over new drug
}

\section{Munich \& London}

AN official of the World Health Organization (WHO) flew to Romania this week to investigate claims that an untried AIDS treatment is being administered to children in a Bucharest hospital. The WHO investigation of the Romanian trials comes on the heels of a separate inquiry into the effects of a 'wonder drug', known as Kemron, that emerged from Kenya (see Nature 347, 416; 1990).

Ever since AIDS became a problem, WHO has been overrun with letters and calls from "all types of people" who want to perform drug trials, says David Heymann, a specialist on AIDS at WHO.

"We don't want to deprive people of good AIDS drugs", says Heymann, "but we do want to see them be tested properly". The Romanian Health Ministry assured WHO by telephone last week that the drug used for the treatment, which is known as FLV 23/A, was harmless and that it would be tested in a double-blind trial using placebo controls under the supervision of physicians. But an official of WHO in Geneva said it would be impossible in the West to test a compound in humans before testing it in the laboratory. In the absence of published toxicity data, WHO was not able to say before the visit began this week if the drug had toxic sideeffects.

The drug used in Romania was developed by David Hughes, a 61-year-old Scottish inventor and researcher. Hughes, in the company of several paediatricians, began earlier this month to administer the drug to about $100 \mathrm{HIV}$-positive babies, mostly orphans, and adults.

Romania is going ahead with the trials despite warnings from the British Foreign Office, which expressed doubts about Hughes' background and the claims he had made for the drug. Hughes claims to have a doctorate in "hyperbaric physiology" from the University of Grenoble, according to the curriculum vitae Hughes presented to the Dubai-based International Medical Research Foundation (IMRF), which is paying for the research he is doing.

Nicolae Beldescu, director of the Romanian AIDS programme, defended the decision to go ahead with the treatments, saying that they had been approved by the National Drug Commission after toxicity tests on guinea pigs. Beldescu said that the commission concluded that it would be worth continuing the treatments "if only one baby is helped".

According to IMRF, the drug, which is based on oxides of hexylene based on cyclohexane, "will attack the AIDS virus and other similar viruses". Beldescu stressed that Hughes had never promised to "cure" AIDS patients, just to help them "recover". Western AIDS experts were not familiar with any successful treatment based on such a compound, which is not listed in drug reference books.

Hughes had tried the compound last year on AIDS patients in the main hospital in Lilongwe, the capital of the East African state of Malawi, but the positive results that he claims from the trials were negated by a lack of controls, say people familiar with the experiments.

A Western researcher who spent time in Malawi earlier this year, Lutz Gürtler of the University of Munich, said that before Hughes left Malawi physicians there had expressed suspicions about the legitimacy of his work.

Peter Desjardins, a board member of IMRF, says the trials, which also involve dietary restrictions, could not be properly run because some of the patients left the hospital at times. IMRF was founded in 1988 by private investors "largely" in order to support Hughes' research, says Desjardins.

Steven Dickman \& Peter Aldhous NATURE · VOL $347 \cdot 18$ OCTOBER 1990 